Endicrinol. Japon. 1968, 15 (1), 94 100

\title{
DEMONSTRATION OF INTERMEDIARY CELL BETWEEN LIPID CELL AND SUMMER CELL IN ADRENAL CORTEX OF BULLFROGS
}

\author{
FUJIO YOSHIMURA AND KANJI HARUMIYA \\ Department of Anatomy, Jikei University \\ School of Medicine, Tokyo
}

\begin{abstract}
SYNOPSIS
The adrenal glands from April, July and November bullfrogs (Rana catesbeiana) were investigated cytologically on the preparations of tissues fixed with osmic acid solution, embedded in Epon and stained with toluidin blue. In the adrenal gland of the bullfrog two kinds of cortical cells were distinguished: the lipid cell containing many fat vacuoles, and the acidophilic summer cell loaded with acidophilic dense granules. In addition, the intermediary cell between the lipid and summer cell was successfully demonstrated. The identification of this intermediary cell was possibly due to the cellular characteristic that the dense granules are intermingled with abundant fat vacuoles. The dense granules were scattered in the cytoplasm, and gradually increased in number especially during the breeding and summer seasons. Eventually, the cell-body became full of dense granules, but lost the fat vacuoles. When this cell acquired an ellipsoid, or spherical contour, it turned into acidophilic summer cell. The occurrence of intermediary cell suggests the transformation of lipid cell into summer cell in the amphibian adrenals.
\end{abstract}

It has been generally accepted that there are two different type cells $\sim$ the polygonal lipid cell containing many lipid vacuoles, and the spherical or ellipsoid summer cell loaded with dense granules-in the adrenal cortex of the bullfrog. Recently, Nakamura (1967), Sekiguchi (1968) and Suzuki (1968) suggested a possibility of lipid cell to turn into summer cell by storing acidophilic granules in the bullfrog. The authors have demonstrated a reliable evidence for occurrence of an intermediary cell type on the occasion of transformation of lipid cell into summer cell in April and July bullfrogs.

\section{MATERIALS AND METHODS}

Nine male bullfrogs (Rana catesbeiana) weigh-

Received for publication January 6, 1968. ing 310 - 350g were used. Three in April (breeding period), three in July (summer season) and the remainder in November (hibernating period). The adrenal glands were removed for fixation. The smail pieces were fixed with $2 \%$ osmium tetroxyde in pH 7.4 veronal acetate buffer solution for $2 \mathrm{hrs}$., and embedded in epoxy resin 812 by method of Luft (1961). About $1 \mu$ thick sections were cut with Porter-Blum ultratome, and stained with toluidin blue after the procedure of Yamamoto (1963).

\section{OBSERVATION}

By observation on our preparations, it was revealed that the shape of lipid cell is rather indistinct during breeding and summer seasons because of the obscure borders of adjoining cells (Figs. 1 and 2). Lipid cells contain a great amount of fat vacuoles ap- 
pearing sometimes quite vacuolar, and sometimes yellow, and measuring approximately $1 \mu$ in diameter in November, $0.5 \mu$ in April and $0.3 \mu$ in July. The lipid cell is characterized by a package of fat vacuoles during hibernation (Figs. 3 and 4), while it contains a small quantity of fine lipid vacuoles during breeding and summer seasons, corresponding to the "compact type" described by Van Kemenade and Van Donger (1965) (Figs. 1 and 2).

The dense granules found in the lipid cells vary in size, from 0.2 to $0.7 \mu$ in diameter, and deeply stained with toluidin blue so that they were sharply outlined. They are initially scattered among lipid vacuoles (Figs. 5, 6, 7 and 8). In this observation it was not possible to determine where these dense granules were produced. However, in other lipid cells of April and July frogs, they tended to accumulate in the vicinity of nuclei (Fig. 6). When they increased extraordinarily in number, a large portion of the cell-body was occupied by them intermingled with lipid vacuoles. Such cells with a package of dense granules were subject to form a culster (Figs. 5 and 8) where the cell remained to be indistinct in shape. Finally, when these cells acquired a spherical or ellipsoid contour (Fig. 5), they lost their fat vacuoles in order to change themselves into acidophilic summer cell. Intermediary cells, compact type lipid cell containing dense granules, were not scattered uniformly in the widespread areas of the gland, but tended to be concentrated somewhere. The coexistence of fat vacuoles and dense granules within one cell is a morphological criterion to identify the intermediary cell between lipid and summer cells.

During the hibernating period, there were many lipid cells having no dense granules. They had quite a different internal structure being compared with that of summer cells. But certain lipid cells exceptionally include some dense granules in addition to abundant fat vacuoles (Figs. 3 and 4). Consequently, intermediary cells were less numerous in November frogs than in summer frogs. The spherical mitochondria intervening among fat vacuoles in the lipid cells were so weakly stained with toluidin blue that it was difficult to identify mitochondria by light microscopy. The demonstrable granular elements in the cell-body might belong to the dense granules.

\section{DISCUSSION}

Primarily it must be discussed whether or not the dense granules scattered in the cytoplasm of intermediary cell are compatible in nature with the dense granules in the summer cell. The problem probably lies in the differential diagnosis of dense granules from the mitochondria. The typical lipid cells which may be in the resting phase are devoid of dense granules in the summer frogs. Especially in the hibernating November frogs there were few dense granules in the "stabilized" lipid cells. The dense granules were stained intensively, while the mitochondria stained weakly were not clearly discernible by toluidin blue stain. These properties support the view that the dense granules scattered in the cytoplasm of the lipid cell are identical with those concentrated in the summer cell.

Nakamura (1967) pointed out that the acidophilic summer cell becomes hypertrophic and proliferate in the highest degree during the breeding period (April). The intermediary cell demonstrated in the present observation might be inherent in the hypertrophied acidophilic summer cell containing less acidophilic granules. In the ACTH administered bullfrogs, the lipid cell is susceptible of having the character of summer cell by storing the acidophilic granules (Suzuki 1968). In particular, a single administration of ACTH to hibernating frogs enabled the lipid cell to rapidly turn into summer cell within a short period of 30 mins. In consideration of this quick response observed in the summer cell, it was claimed by Suzuki that the augmentation in number of acidophilic cell is not due to cell-division, but to cellular transformation. Concerning the homology of these two cells in the Amphibia, Suzuki considered that the 
immature lipid cell may be homologous to the glomerulosa cell, but he did not present evidences that the summer cell surely corresponds to the reticularis cell in mammals. The present demonstration of the intermediary cell strengthened the theory of cellular transformation from lipid to summer cell.

Fig. 1. Adrenal gland from an April bullfrog. Many lipid cells contain not only fat vacuoles but also dense granules. S, summer cell; IL, immature lipid cell which is identical with the "compact cell type". $\times 880$

Fig. 2. From a July bullfrog. Most lipid cells have dense granules together with scanty of fat vacuoles. These cells are inherent in the intermediary cells between summer and lipid cells. S, summer cell. $\quad \times 880$

Fig. 3. From a November bullfrog. A clear distinction is possible between lipid (L) and summer cells (S). In November, lipid cells are loaded with fat vacuoles of large size. Mitochondria are not easily discernible among fat vacuoles. M, medullary cell. $\quad \times 880$

Fig. 4. From a November bullfrog. During hibernation the lipid cell $(L)$ is in the resting or storage phase, but the dense granules are occasionally accumulated in some areas (arrow) of lipid cells. M, medullary cell. $\quad \times 880$ 

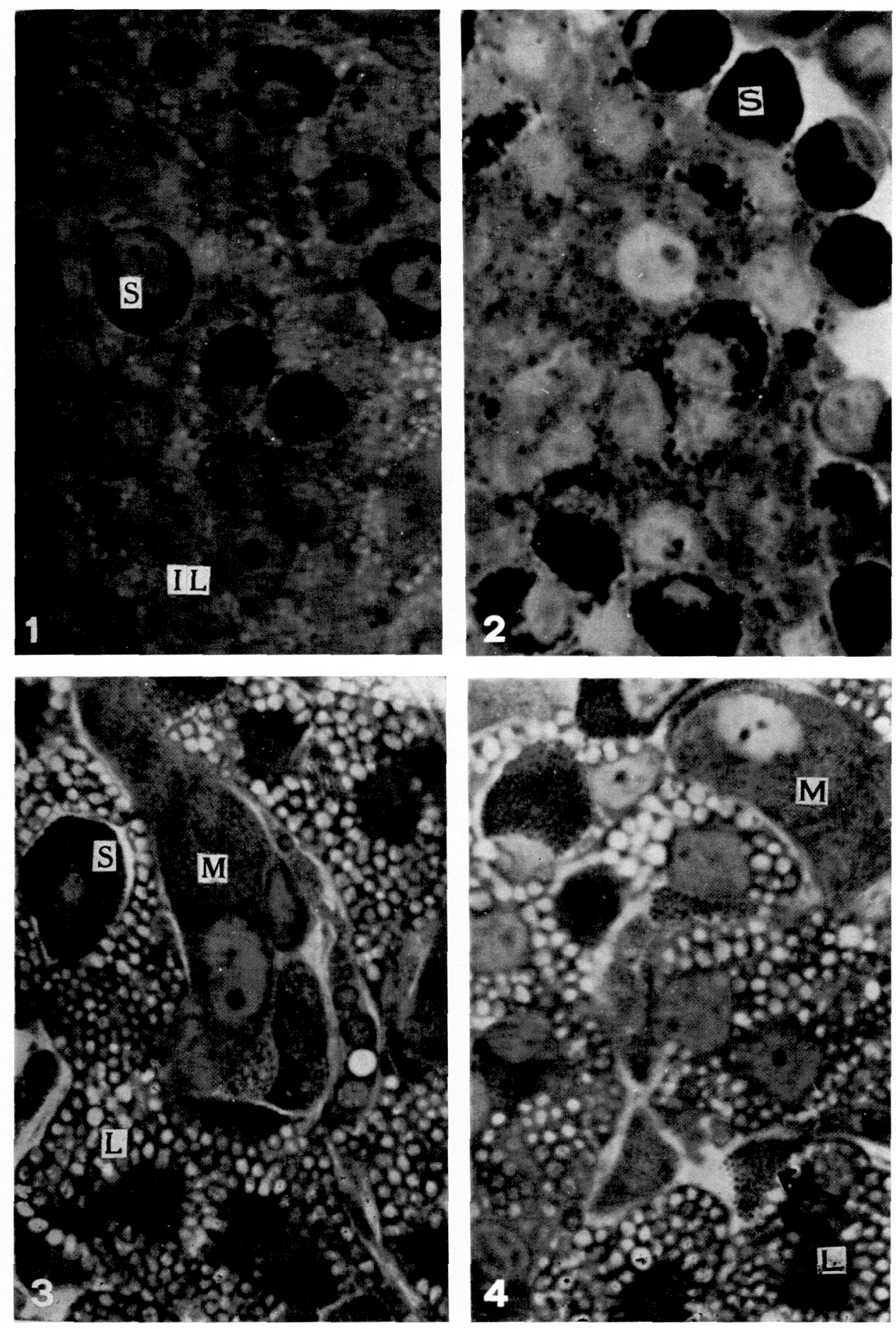
Fig. 5. From an April bullfrog. The intermediary cell (IC) is shown by higher magnification. The coexistence of fat vacuoles and dense granules is a characteristic of the intermediary cell. The package of dense granules is followed by transformation of lipid cell into summer cell $(\mathrm{S}) . \quad \times 1350$

Fig. 6. From an April bullfrog. The dense granules are accumulated near the nucleus. This may be in an early stage of the intermediary cell (IC).

$\times 1350$

Fig. 7. From an April bullfrog. In the intermediary cell, the dense granules are generally scattered in the cytoplasm, being intermingled with fat vacuoles, and sometimes makes accumulations. The two cells (IC) at the bottom may be in the initial stage of transformation into summer cell. $\quad \times 1350$

Fig. 8. From a July bullfrog. The intermediary cells in which dense granules are progressively accumulated tend to form a cluster. $\times 1350$ 

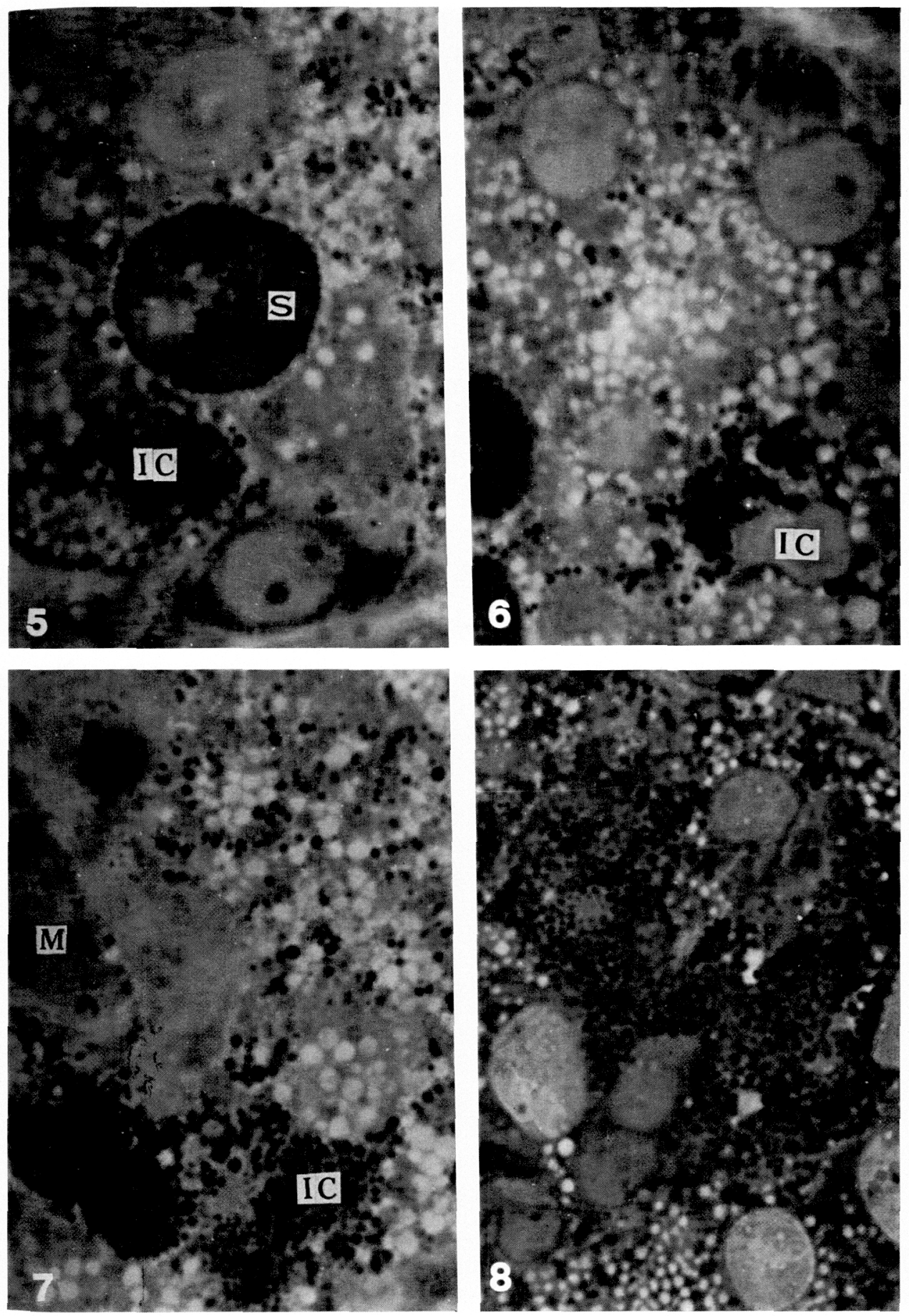


\section{REFERENCES}

Kemenade Van J. A. and W. J. Van Dongen (1965). Nature 205, 4967.

Luft, J. H. (1961). J. Biophys. Biochem. Cytol. 9, 409.
Nakamura, M. (1967). Endocrinol. Japon. 14, 43. Sekiguchi, T. (1968). Ibid. 15, 70.

Suzuki, N. (1968). Ibid. 15, 82.

Yamamoto, T. (1963). Fol. Anat. Jap. 38, 124. (In Japanese) 